\section{ON AN ACOUSTIC PHENOMENON NOTICED IN A CROOKES TUBE ${ }^{1}$} A SHORT time since, while experimenting with a Crookes
tube, I noticed a phenomenon which was quite striking,
and so evident that it hardly seems possible that it has not fre-
quently been observed before; but as no allusion to the effect
in question has come to my notice, I venture to call attention
to it.
In working with the tube in which a piece of sheet platinum is rendered incandescent by the concentration upon it of electrified particles, repelled from a concave mirror, I noticed that when the mirror was made the negative electrode, so that this concentration took place, a clear and quite musical note issued from the tube. I thought at first that the pitch of the note would coincide with that produced by the circuit-breaker used with the coil (which made about roo breaks per second), but this did not prove to be the case. In fact very great changes in the rate of the circuit-breaker did not affect the note given by the tube. The effect seemed to be produced by the vibration of the sheet-platinum in its own period, under the influence of the molecular impact, which vibration was communicated to the glass walls of the tube by the enamel rod to which the platinum was attached, giving rise to a spund somewhat resembling the pattering of rain against a window-pane, but higher in pitch and more musical. This sound changed its character very greatly when the direction of the current was reversed, a feeble murmur only being heard. I obtained a similar musical note, though far less loud, with the "mean free-path tube," best when the middle plate was positive. With a tube containing phosphorescent sulphide of calcium, the note was very dull in its quality and low in pitch, but still quite perceptible. With this tube a change in the direction of the current, as might be expected, did not affect the sound produced. I did not obtain this musical note from any tube that $I$ have in which the current enters and leaves by a straight wire, except in the case of a single Geissler's tube exhausted so as to give stratifications, in which it was very feebly heard.

\section{UNIVERSITY AND EDUCATIONAL INTELLIGENCE}

A LARGE number of ladies and gentlemen assembled on Tuesday in Cowper Street to witness the laying of the foundation-stone of the Finsbury Technical College which it has lately been resolved to establish by the City and Guilds of London Institute, by His Royal Highness Prince Leopold. According to the report of the Council of the Institute to the Governors, the projected building is estimated to cost $20,382 l$., exclusive of the professional charges, fittings, and other incidental expenses, which will amount to some $5000 \mathrm{l}$. In the plans ample accom modation is provided for instruction in the application of physics, chemistry, and mechanics to the various industries. The building will contain thirty-two rooms, including a large laboratory, two lecture theatres, class, drawing, private, and engine rooms, workshops, and clerks' offices. Lord Selborne, in welcoming the Prince, after noting the progress of science as applied to arts and manufactures in this and other countries, said that in the race of competition the prize must in the end belong to those who best knew how to build the superstructure of arts and manufacture on their handicrafts with a sound foundation of scientific knowledge. The ceremony of laying the stone was gone through by Prince Leopold, who in the course of his remarks said that the institution has proclaimed its determination to enter into generous rivalry with other countries in those branches of trade and commerce in which, one must needs confess, our native in dustries have of late years not taken that position which we as Englishmen would wish them to occupy. We are beginning to realise that a thorough and liberal system of education must be placed within the reach of the British artisan in order to enable him to hold his own against foreign competition. Mr. Mundella said that by instituting this college they were taking the same step in applying science to industries which had been taken in applying arts to manufactures at South Kensington. Among the articles deposited in the cavity of the foundation-stone was a COPY of NATURE.

I Read by C. R. Cross at a meeting of the American Academy of Arts and Sciences, November xo, $x 880$.
THE Berlin correspondent of the Times states that a movement is afoot among the Germans in the United States for the creation of a native University on the model of those in the old country, to be called the Kaiser Wilhelm Universität, in commemoration of the "glorious resuscitation of the Fatherland." Milwaukee is mentioned as the likeliest candidate among all the cities of the West that aspire to the honour of harbouring this plant of pure Teutonic culture, which would cost, to begin with, about two million dollars. It is not at all probable, however, that the scheme will come to anything.

\section{SCIENTIFIC SERIALS}

THE Fournal of Anatomy and Physiology for April, 1881 (vol. xv. part 3), contains :- On the bones, articulations, and muscles of the rudimentary hind-limb of the Greenland right whale (Balana mysticetus), by Dr. J. Struthers.-On the stridulating apparatus of Callomystax gagata, by Prof. A. C. Haddon (Plate 20).- - On the sternum as an index of age and sex, by Dr. Thomas Dwight (concludes that the breast-bone is no trustworthy guide either to the sex or the age).-On the mechanism of costal respiration, by Dr. J. M. Hobson (with figures).-On the membrana propria of the mammary gland, by Dr. C. W. M. Moullin (with figures). - On double and treble staining of microscopical specimens, by Dr. W. Stirling.-On the comparative anatomy of the lymphatics of the mammalian urinary bladder, by Drs. George and F. Elizabeth Hoggan (plate 2I). - Notes on a dissection of a case of epispadias, and on the morphology of the muscles of the tongue and pharynx, by Dr. R. J. Anderson. -On the so-called movements of pronation and supination in the hind-limb of certain marsupials, by Dr. A. H. Young.-A contribution to the pathological anatomy of pneumonokoniosis (Chalicosis pulmonum), by Thos. Harris (plate 22). - On the histology of some of the rarer forms of malignant bone tumours, by Robt. Maguire.-On the morbid histology of the liver in acute yellow atrophy, by Prof. Dreschfeld.-On the relationship between the muscle and its contraction, by Dr. J. Theodore Cash. -Anatomical notes.

The Quarterly Fournal of Microscopical Science, April, I88r, contains-On the minute anatomy of the branchiate echinoderms, by P. Herbert Carpenter (plates 11 and 12).- On young stages of Limnocodium and Geryonia (plate 13), and observa. tions and reflections on the appendages and on the nervous system of Apus cancriformis, by E. Ray Lankester (plate 20).On the origin and significance of the metamorphosis of Actinotrocha, by Edround B. Wilson (plates 14 and 15). - A further contribution to the minute anatomy of the organ of Jacobson in the guinea-pig (plates I6 and 17), and histological notes, by Dr. E. Klein.-On the development of microscopic organisms occurring in the intestinal canal, by Dr. D. Cunningham (plate r 8 ). $-\mathrm{Re}$ searches upon the development of starch-grains, by A. F. W. Schimper (plate 19), translated from the Botanische Zeitung.On the cause of the striation of voluntary muscular tissue, by Dr. J. B. Haycraft.-On the relation of micro-organisms to disease, by Prof. Lister; with notes and memoranda.

The American Naturalist, April, 1881.-Wm. Trelease, on the fertilisation of Salvia splendens by birds. (The fertilisation is apparently effected by a humming-bird.)-Prof. E. D. Cope, on the origin of the foot-structures of the Ungulates. - C. A. White, progress of invertebrate palæontology in the United States for I880.-Carl F. Gissler, evidences of the effect of chemico-physical influences on the evolution of branchiopod Crustaceans. -Dr. R. W. Schufeldt, notes on a few of the diseases and injuries of birds. -A. S. Packard, jun., the brain of the locust (with three plates).

Bulletin of the United States Geological and Geographical Survey of the Territories, vol. vi. No, 1.- On the vegetation of the Rocky Mountain region and a comparison with that of other parts of the world, by Asa Gray and Joseph D. Hooker (pp. r, 77).-On some new Batrachia and Reptilia from the Permian beds of Texas; on a wading bird from the Amyzon shales; on the Nimravidæ and Canidæ of the Miocene period; and on the Vertebrata of the Wind River Eccene beds of Wyoming, by E. D. Cope.-The osteology of Speotyto cuntcularia, var. hypogaa, and on the osteology of Eremophila alpestris, by Dr. R. W. Schufeldt.-A preliminary list of the North American species of Agrotis, by A. R. Grote. 